\title{
Modulation of Fibrinolytic and Gelatinolytic Activity during Adipose Tissue Development in a Mouse Model of Nutritionally Induced Obesity
}

\author{
H. Roger Ljnen, Erik Maquoi, Diego Demeulemeester, Berthe Van Hoef, Désiré Collen
}

Center for Molecular and Vasc ular Biology, University of Leuven, Leuven, Belgium

Keywords

Obesity, adipose tissue, fibrinolysis, gelatinase

\section{Summary}

A nutritionally induced obesity model was used to investigate the modulation of fibrinolytic and gelatinolytic activity during the development of adipose tissue.

Five week old male mice were fed a standard fat diet (SFD, $13 \% \mathrm{kcal}$ as fat) or a high fat diet (HFD, $42 \% \mathrm{kcal}$ as fat) for up to 15 weeks. The HFD resulted in body weights of $31 \pm 0.9 \mathrm{~g}, 38 \pm 2.0 \mathrm{~g}$ and $47 \pm 1.9 \mathrm{~g}$ at 5, 10 and 15 weeks, respectively; corresponding values for mice on the SFD were $26 \pm 0.6 \mathrm{~g}, 31 \pm 0.9 \mathrm{~g}$ and $31 \pm 1.2 \mathrm{~g}$ (all $\mathrm{p}<0.001)$. The weight of the isolated subcutaneous (SC) or gonadal (GON) fat after 15 weeks of HFD was $1,870 \pm 180 \mathrm{mg}$ or $1,470 \pm 160 \mathrm{mg}$, as compared to $250 \pm 58 \mathrm{mg}$ or $350 \pm 71 \mathrm{mg}$ for the SFD ( $<<0.001)$. The HFD induced marked time-dependent hyperglycemia and elevated levels of triglycerides and total cholesterol. The HFD diet also induced a marked hypertrophy of the adipocytes as compared to the SFD, e.g. diameter of $83 \pm 3.0 \mu \mathrm{m}$ versus $52 \pm 4.2 \mu \mathrm{m}$ for GON adipocytes at 15 weeks ( $\mathrm{p}<0.005)$. Plasma plasminogen activator inhibitor-1 (PAI-1) levels were higher in mice on the HFD as compared to the SFD; they were comparable in extracts of SC or GON adipose tissue, whereas at different time points tissue-type (t-PA) and urokinase-type (u-PA) plasminogen activator activity was somewhat lower in the adipose tissues of mice on HFD. Gelatinolytic activity (mainly MMP-2) was detected in SC but not in GON adipose tissue of mice on SFD, and decreased on the HFD. In situ zymography on cryosections did not reveal different fibrinolytic activities in SC or GON adipose tissues of the HFD as compared to the SFD groups, whereas significantly lower gelatinolytic and higher caseinolytic activities were detected in SC and GON tissues of mice on the HFD ( $\mathrm{p} \leq 0.05$ ). The fibrillar collagen content was lower in adipose tissue of mice on HFD. Thus, in this model time-dependent development of adipose tissue appears to be associated with modulation of proteolytic activity.

\section{Introduction}

Obesity is a common disorder and its related diseases such as non-insulin-dependent diabetes mellitus, cardiovascular disease, atherosclerosis and hypertension are a main cause of death and disability in Western societies. Development of obesity is associated

Correspondence to: H.R. Lijnen, Center for Molecular and Vascular Biology, University of Leuven, Campus Gasthuisberg, O and N, Herestraat 49, B-3000 Leuven, Belgium - Tel.: 32-16-345775; Fax: 32-16-345990; E-mail: roger.lijnen@med.kuleuven.ac.be with extensive modifications in adipose tissue involving adipogenesis, angiogenesis and extracellular matrix (ECM) remodeling (1). Proteolytic systems, e.g. the matrix metalloproteinase (MMP) and the plasminogen/ plasmin (fibrinolytic) system, contribute to tissue remodeling by degradation of ECM and basement membrane components or activation of latent growth factors (2-4). The fibrinolytic system contains a proenzyme, plasminogen, that is converted to the active enzyme plasmin by tissue-type (t-PA) or urokinase-type (u-PA) plasminogen activator. Plasmin degrades fibrin and can convert latent matrix metalloproteinases (proMMPs) into active MMPs which in turn degrade the ECM. Plasmin mediated effects are inhibited by $\alpha_{2}$-antiplasmin and MMP-mediated effects by tissue inhibitors (TIMPs). Plasminogen activators are also inhibited by plasminogen activator inhibitors (mainly PAI-1) (4). PAI-1 is highly expressed in adipose tissue and may play a role in the development of obesity (5-9). PAI-1 deficient mice kept on a high fat diet indeed develop more adipose tissue than their lean counterparts (9), and transgenic mice overexpressing PAI-1 have virtually no intraperitoneal fat (10). Conditioned medium of rat adipocytes contains a MMP-2 (gelatinase A) like gelatinolytic activity, that may play a role in their organization into large multicellular clusters (11). High expression of MMP-2 was reported in adipose tissue of mice with nutritionally induced obesity as well as in genetically obese mice (12), and in human adipose tissue (13). A detailed analysis of the expression of MMP system components in adipose tissue of lean and obese mice revealed upregulation with obesity of mRNA levels of MMP-3, -11, -12, -13, -14 and TIMP-1, and downregulation of MMP-7, -9, -16, -24 and TIMP-4 (14). Several lines of evidence thus indicate a potential role of the fibrinolytic and MMP systems in adipose tissue development.

Specific molecular interactions between both systems furthermore suggest that they may cooperate in achieving matrix degradation (4). We have used a nutritionally induced obesity model in mice to monitor fibrinolytic and gelatinolytic activity as a function of time during development of adipose tissue.

\section{Materials and Methods}

\section{Diet Model}

Five week old male mice with a $75 \% \mathrm{C} 57 \mathrm{Bl} / 6: 25 \% 129 \mathrm{SvJ}$ or $81 \%$ C57B1/6: 19\% $129 \mathrm{SvJ}$ genetic background weighing about $20 \mathrm{~g}$, were kept in micro-isolator cages on a 12-h day/night cycle and fed water and a standard fat diet (SFD) or high fat diet (HFD) ad libitum. The SFD (4\%, w/w, fat, 13\% kcal as fat; KM-04-k12, Muracon, Carfil) contains (g/kg) crude protein (216), fiber (43), fat (50), ash (62), mineral mix and vitamin mix. The HFD (TD 88137, Harlan Teklad, Madison, WI) contains ( $\mathrm{g} / \mathrm{kg}$ ) casein (195), DL-methionine (3.0), sucrose (341), corn starch (150), anhydrous milkfat (210), cholesterol (1.5), cellulose (50), mineral mix AIN-76 (35), CaCO3 (4.0), vitamin mix (10), and ethoxyquin (0.04); this corresponds to $21 \%$, w/w, fat coming from milk fat and $49 \%$, w/w, carbohydrate coming from sucrose and corn starch, yielding $42 \% \mathrm{kcal}$ as fat. 
Mice were weighed every week. Food intake was measured for $48 \mathrm{~h}$ periods at weekly intervals from week 4 to 11 of the diet period, and expressed as g per $24 \mathrm{~h}$. To evaluate physical activity, mice were placed in a separate cage equipped with a turning wheel linked to a computer to register full turning cycles in $48 \mathrm{~h}$ periods during weeks 4 to 11 of the diet; data are represented as number of cycles per $12 \mathrm{~h}$. At the end of the diet period, following overnight fasting the mice were anesthetized by i.p. injection of $60 \mathrm{mg} / \mathrm{kg}$ Nembutal (Abbott Laboratories, North Chicago, IL). All animal experiments were approved by the local ethical committee and were performed in accordance with the guiding principles of the American Physiological Society and the International Society on Thrombosis and Haemostasis (15).

\section{Blood Collection and Tissue Preparation}

Blood was collected from the retroorbital sinus with or without addition of trisodium citrate (final concentration $0.01 \mathrm{~mol} / \mathrm{L}$ ); plasma and serum were stored at $-20^{\circ} \mathrm{C}$. Intra-abdominal (gonadal, GON) and inguinal subcutaneous (SC) fat pads were removed and the wet weight determined. The SC fat pad represented the adipose tissue overlying the posterior iliac crest and was dissected from its attachment sites to the skin. One portion of fat tissue was immediately frozen at $-80^{\circ} \mathrm{C}$ for protein and mRNA extraction, other portions were used for histology.

Other organs, including lungs, kidneys, liver, spleen and heart were also removed, weighed and stored at $-20^{\circ} \mathrm{C}$.

\section{Haemostatic and Metabolic Parameters}

White blood cells, red blood cells, platelets, haemoglobin and haematocrit levels were determined using standard laboratory assays. PAI-1, t-PA, and u-PA antigen levels were measured with specific ELISA's (16).

Blood glucose concentrations were measured using Glucocard strips (Menarini Diagnostics). For glucose tolerance tests, glucose $(2 \mathrm{mg} / \mathrm{g}$ body weight) was injected intraperitoneally and glucose levels were measured at different time points (0-120 $\mathrm{min})$ after injection. Triglycerides, and total cholesterol were evaluated using routine clinical assays.

\section{Zymographic Analysis}

Extraction of adipose tissue (about $250 \mathrm{mg} / \mathrm{ml}$ ) was performed by overnight incubation at $4^{\circ} \mathrm{C}$ on a tilting table in $10 \mathrm{mmol} / \mathrm{L}$ sodium phosphate buffer, $\mathrm{pH}$

\begin{tabular}{|c|c|c|c|c|c|c|}
\hline \multirow[t]{2}{*}{ Parameter } & \multicolumn{2}{|c|}{5 weeks } & \multicolumn{2}{|c|}{10 weeks } & \multicolumn{2}{|c|}{15 weeks } \\
\hline & SFD & HFD & SFD & HFD & SFD & HFD \\
\hline Weight gain (g) ${ }^{(a)}$ & $9.3 \pm 1.3$ & $13 \pm 0.8$ & $12 \pm 1.5$ & $17 \pm 2.4$ & $13 \pm 1.1$ & $30 \pm 1.3^{* *}$ \\
\hline Body weight $(\mathrm{g})^{(\mathrm{b})}$ & $26 \pm 0.6$ & $31 \pm 0.9 * * *$ & $31 \pm 0.9$ & $38 \pm 2.0 * * *$ & $31 \pm 1.2$ & $47 \pm 1.9 * * *$ \\
\hline Body weight $(\mathrm{g})^{(\mathrm{c})}$ & $23 \pm 1.1$ & $31 \pm 1.3 * *$ & $26 \pm 0.7$ & $38 \pm 1.4 * * *$ & $28 \pm 0.8$ & $44 \pm 1.7 * * *$ \\
\hline SC fat (mg) & $97 \pm 12$ & $630 \pm 150 * *$ & $200 \pm 39$ & $1460 \pm 200 * * *$ & $250 \pm 58$ & $1870 \pm 180 * * *$ \\
\hline GON fat (mg) & $186 \pm 23$ & $900 \pm 180 * * *$ & $270 \pm 46$ & $1530 \pm 120 * * *$ & $350 \pm 71$ & $1470 \pm 160 * * *$ \\
\hline \multicolumn{7}{|c|}{ Adipocyte number $\left(\mathrm{x} 10^{-6} / \mu \mathrm{m}^{2}\right)$} \\
\hline SC & $1,670 \pm 180$ & $820 \pm 230 *$ & $1,560 \pm 320$ & $400 \pm 36 * * *$ & $880 \pm 150$ & $270 \pm 27 * *$ \\
\hline GON & $890 \pm 70$ & $320 \pm 42 * * *$ & $720 \pm 120$ & $210 \pm 56 * * *$ & $550 \pm 98$ & $195 \pm 12 * *$ \\
\hline \multicolumn{7}{|c|}{ Adipocyte diameter $(\mu \mathrm{m})$} \\
\hline SC & $29 \pm 1.8$ & $48 \pm 7.0^{*}$ & $31 \pm 2.1$ & $59 \pm 3.0 * * *$ & $41 \pm 2.6$ & $71 \pm 2.0 * *$ \\
\hline GON & $39 \pm 1.7$ & $66 \pm 4.0 * * *$ & $45 \pm 3.2$ & $78 \pm 1.0 * * *$ & $52 \pm 4.2$ & $83 \pm 3.0 * *$ \\
\hline \multicolumn{7}{|c|}{ Data are mean \pm SEM of 6 to 12 experiments; ${ }^{*}, \mathrm{p}<0.05,{ }^{* *}, \mathrm{p}<0.005$ and ${ }^{* * *}, \mathrm{p}<0.001$} \\
\hline \multicolumn{7}{|c|}{${ }^{\text {(a) }}$ Weight gain at the end of the diet period. } \\
\hline \multicolumn{7}{|c|}{ 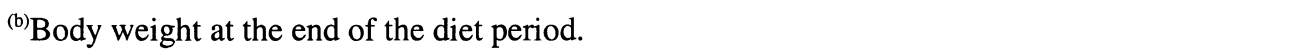 } \\
\hline
\end{tabular}

Table 1 Time course of adipogenesis in wild-type mice kept on SFD or HFD 
Fig. 1 Evolution of the body weight of wild-type mice kept on SFD $(\mathbf{\square})$ or HFD $(\bullet)$. Data are mean \pm SEM of 19 to 24 determinations up to 5 weeks, of 11 to 16 determinations up to 10 weeks and of 6 to 9 determinations up to 15 weeks of diet. ${ }^{*} p<0.01$

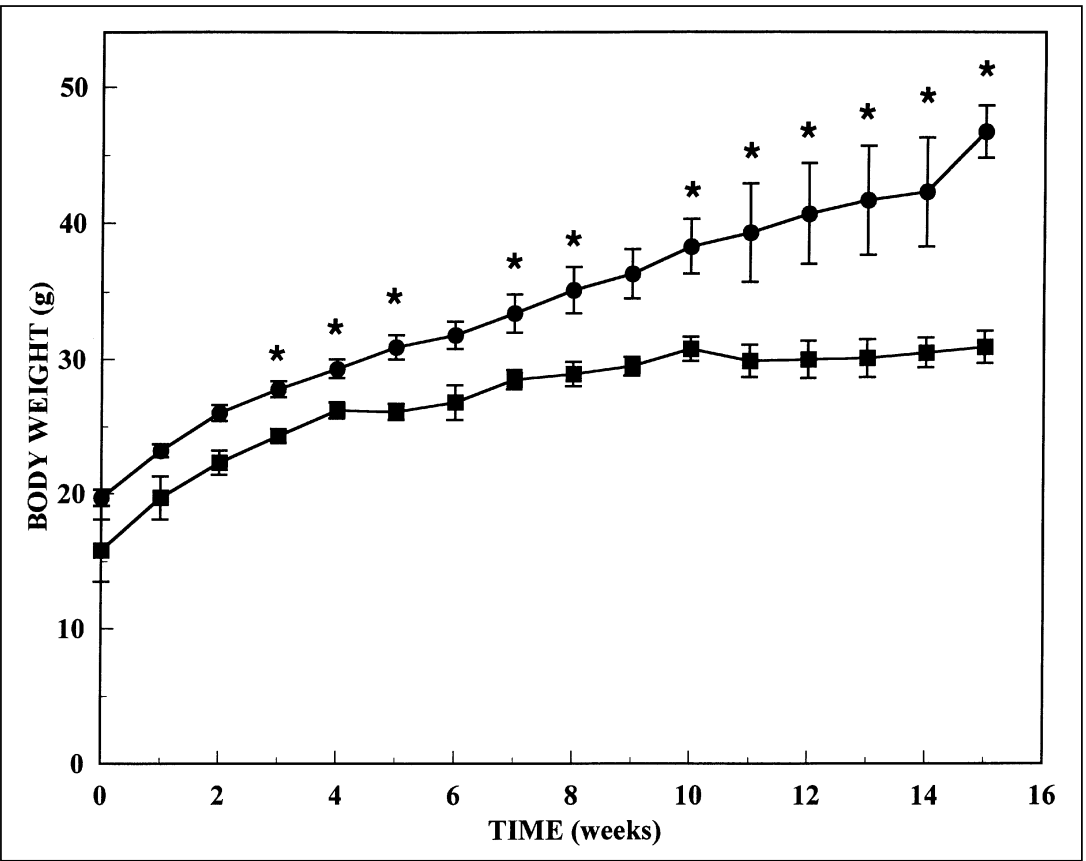

7.2, containing $150 \mathrm{mmol} / \mathrm{L} \mathrm{NaCl}, 1 \%$ Triton X-100, 0.1\%SDS, $0.5 \%$ sodium deoxycholate and $0.2 \% \mathrm{NaN}_{3}$. After centrifugation, the protein concentration of the supernatant was determined (BCA assay, Pierce) and the extracts were stored at $-80^{\circ} \mathrm{C}$.

Zymographic analysis of plasminogen activator activity (t-PA or u-PA) was performed after electrophoresis of adipose tissue extracts ( $40 \mu \mathrm{g}$ total protein) on a $12 \%$ acrylamide gel cast with $1 \%$ nonfat dry milk and $5 \mu \mathrm{g} / \mathrm{ml}$ human plasminogen under nonreducing conditions (17). Zymographic analysis of gelatinase activity in adipose tissue extracts ( $20 \mu \mathrm{g}$ total protein) was performed on $10 \%$ Tris-glycine gels with $0.1 \%$ gelatin (18). The lysis of the substrate gel was quantified using Quantimed 600 image analysis software (Leica) and expressed in arbitrary units obtained per $\mathrm{g}$ of adipose tissue, to correct for different total protein concentrations in the extracts (17). Because of different efficiencies for lysis of the substrate gel, u-PA and t-PA activities cannot be directly compared.

In situ zymography on $10 \mu \mathrm{m}$ cryosections of adipose tissue using casein- or gelatin-containing gels was performed essentially as described (19). The substrate gel ( $0.5 \%$ agarose) contained $1.0 \mathrm{mg} / \mathrm{ml}$ resorufin-labeled casein (Boehringer Mannheim) or pig skin gelatin Oregon Green $^{\mathrm{TM}} 488$ conjugate (Molecular Probes BV). Overlays were analysed by computerassisted image analysis (Zeiss, Axioplan 2) after incubation for $24-48 \mathrm{~h}$ in a moist chamber at $37^{\circ} \mathrm{C}$, and the lysis area was normalized to the total section areas.

For in situ zymography of $10 \mu \mathrm{m}$ cryosections of adipose tissue on fibrin overlays a gel was prepared by clotting a mixture of human fibrinogen (final concentration $4 \mathrm{mg} / \mathrm{ml}$ ), plasminogen (final concentration $10 \mu \mathrm{g} / \mathrm{ml}$ ), and agarose (final concentration $0.5 \%$ ) with thrombin (final concentration $0.3 \mathrm{NIH}$ $\mathrm{U} / \mathrm{ml}$ ). Zymography was performed at $37^{\circ} \mathrm{C}$ for $2 \mathrm{~h}$, without or with addition to the gel of neutralizing antibodies against murine t-PA (final concentration $200 \mu \mathrm{g} / \mathrm{ml}$ ). Lysis areas were normalized to the section areas (17).

\section{Morphometric Analysis}

The number of adipocytes (expressed as $\times 10^{-6}$ per $\mu \mathrm{m}^{2}$ ) in $15 \mu \mathrm{m}$ frozen-cut adipose tissue sections, stained with haematoxylin-eosin under standard conditions, and their mean diameter were determined by computer-assisted image analysis. For each animal, 3 to 5 areas in 4 different sections each were analyzed; the data were first averaged per section and then per animal. Staining of fibrillar collagen with Sirius red was performed on paraffine sections, and quantified by computer-assisted image analysis, the stained area is expressed in percent of the section area that is actually measured. Four to nine sections were analyzed per animal and then averaged. Mature adipocytes and stromalvascular $(\mathrm{S}-\mathrm{V})$ cells were isolated from the tissues by collagenase treatment (20). Briefly, minced adipose tissues were digested by incubation in KRB, $\mathrm{pH} 7.3$, supplemented with $3 \%$ (w/v) albumin (KRB-BSA), and $1.5 \mathrm{mg} / \mathrm{ml}$ collagenase (Sigma) on a shaking platform at $37^{\circ} \mathrm{C}$ for $1 \mathrm{~h}$. Undigested tissue fragments were removed by filtration through a nylon screen. Mature adipocytes were separated by their ability to float upon low-speed ( $200 \mathrm{~g})$ centrifugation. The floating fat cell layer was resuspended in KRB-BSA, washed and centrifuged again. The first and second pellets containing $S-V$ cells were pooled after resuspension in the same buffer and centrifuged. Red blood cells contaminating the $\mathrm{S}-\mathrm{V}$ fraction were eliminated using the Red Blood Cell Lysis Buffer (Roche Molecular Biochemicals, Germany) according to manufacturer's instructions. The two cell populations were washed three times with PBS and finally resuspended in $200 \mu \mathrm{PBS}$.

\section{mRNA Determination}

DNA-free total RNAs were extracted from frozen adipose tissues (GON and SC) as well as from isolated mature adipocytes and stromal-vascular cells by the HighPure RNA tissue and HighPure RNA isolation kits (Roche Molecular Biochemicals), respectively, according to the manufacturer's instructions. RNA concentrations were measured using the RiboGreen RNA quantification kit (Molecular Probes). Total RNA samples were diluted in water and stored at $-80^{\circ} \mathrm{C}$ until use.

The expression level of different RNAs was determined with a semiquantitative RT-PCR assay as follows. Specific reverse transcription reactions were performed from $10 \mathrm{ng}$ of total DNA-free RNA with thermostable reverse transcriptase (rTth) at $70^{\circ} \mathrm{C}$ during 15 min using the Gene Amp Thermostable RNA PCR Kit (Applied Biosystems) and target specific antisense primers (GTTTTTGATGCTATTGCTGAGATCCA for MMP-9 and GGATTCTGACTTAGAGGCGTTCAGT for 28S rRNA). For PCR amplifications, the reverse transcription products were added to PCR master mixes containing the target specific sense primers (CCCACATTTGACGTCCAGAGAAGAA for MMP-9 and GTTCACCCACTAATAGGGAACGTGA for $28 \mathrm{~S}$ rRNA). After $120 \mathrm{~s}$ at $95^{\circ} \mathrm{C}$, the $\mathrm{PCR}$ mixtures were subjected to a cycle profile including denaturation for $15 \mathrm{~s}$ at $94^{\circ} \mathrm{C}$, annealing for $20 \mathrm{~s}$ and $30 \mathrm{~s}$ at $68^{\circ} \mathrm{C}$ and $63^{\circ} \mathrm{C}$, extension for $10 \mathrm{~s}$ and $30 \mathrm{~s}$ (cycle profile for $28 \mathrm{~S} \mathrm{rRNA}$ and for MMP-9) at $72^{\circ} \mathrm{C}$ and finally $2 \mathrm{~min}$ extra extension at $72^{\circ} \mathrm{C}$ for the last cycle. The reactions were run for the corresponding number of cycles (44 or 39 for MMP-9 and 19 or 17 


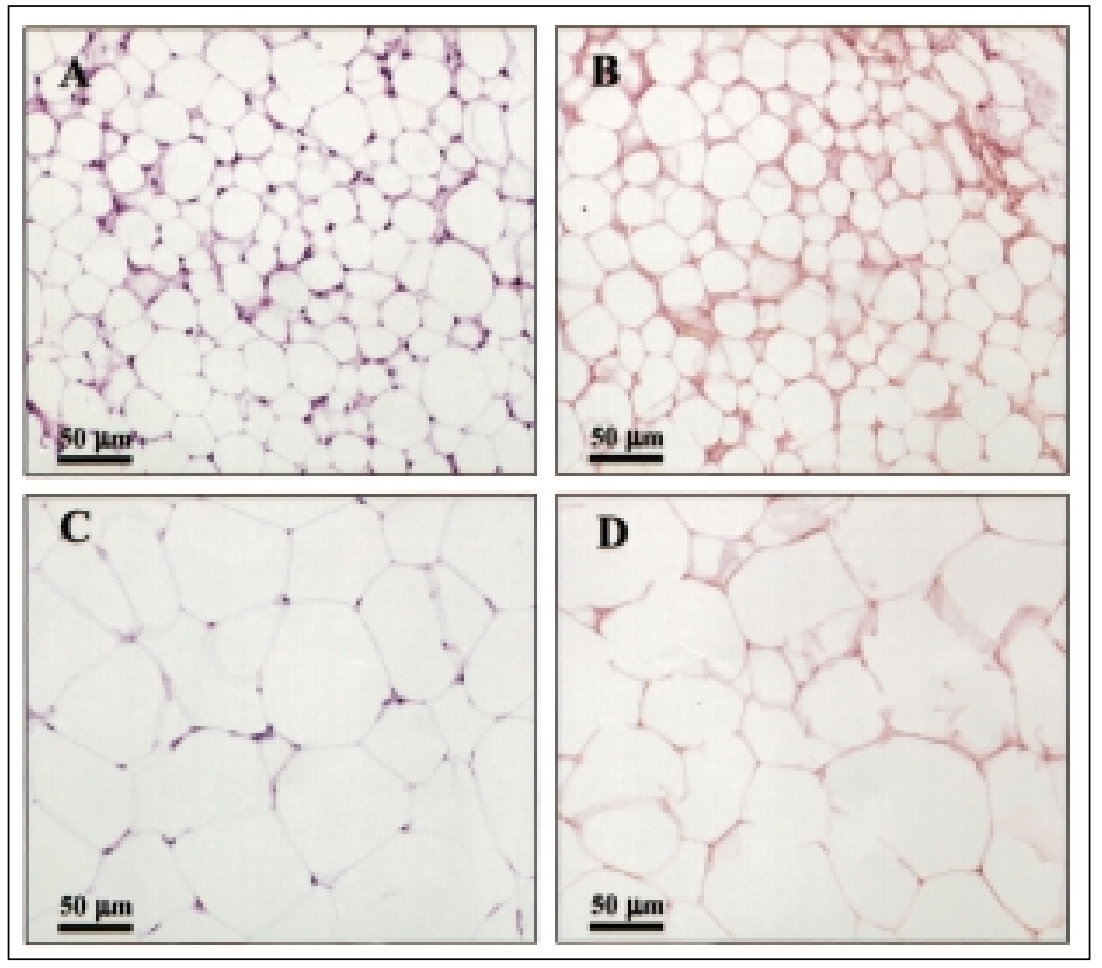

Fig. 2 Histochemical analysis of GON adipose tissue obtained from mice kept on SFD $(A, B)$ or on HFD $(\mathrm{C}, \mathrm{D})$ for 15 weeks. Staining was performed with haematoxylin-eosin (A and C), or Sirius red (B and D) for 28S rRNA in adipose tissue or isolated cells, respectively) in a thermal cycler (GeneAmp9700, Applied BioSystems or PTC100, MJ Research).

RT-PCR products were separated on $10 \%$ acrylamide gels and stained with SYBR Green (Molecular Probes). The expected size of the PCR product is $208 \mathrm{bp}$ for MMP-9 and $212 \mathrm{bp}$ for $28 \mathrm{~S}$ rRNA.

\section{Statistical Analysis}

Data are expressed as mean \pm SEM. Statistical significance between groups was evaluated using non-parametric t-testing. Values of $p<0.05$ were considered statistically significant.

\section{Results}

Evolution of Body and Adipose Tissue Weight

At the start of the diet (5 weeks of age) the body weight of the animals in the SFD and HFD groups was comparable. The increase in body weight with time was higher for the mice on HFD as compared to SFD (Fig. 1 and Table 1). Mice were sacrificed after 5, 10 or 15 weeks on SFD or HFD. At each time point, the weight of the isolated SC or GON fat pads was significantly higher in the HFD groups (Table 1).

\begin{tabular}{|c|c|c|c|c|}
\hline & \multicolumn{4}{|c|}{ Stained area (\% of section area measured) } \\
\hline & \multicolumn{2}{|c|}{$\mathrm{SC}$} & \multicolumn{2}{|c|}{ GON } \\
\hline & SFD & HFD & SFD & HFD \\
\hline 5 weeks & $39 \pm 4.8$ & $13 \pm 4.2^{* *}$ & $10 \pm 1.9$ & $2.4 \pm 0.48 * * *$ \\
\hline 10 weeks & $31 \pm 6.4$ & $8.3 \pm 1.4 * * *$ & $14+2.0$ & $4.7 \pm 0.90 * *$ \\
\hline 15 weeks & $21 \pm 2.3$ & $13 \pm 1.1 *$ & $8.3+2.0$ & $10 \pm 1.3$ \\
\hline \multicolumn{5}{|c|}{ Data are mean \pm SEM of 6 to 8 determinations. } \\
\hline \multicolumn{5}{|c|}{$*, \mathrm{p}<0.05, * *, \mathrm{p}<0.005$ and $* * *, \mathrm{p}<0.001$ versus $\mathrm{SFD}$} \\
\hline
\end{tabular}

Table 2 Fibrillar collagen content in $\mathrm{SC}$ or GON adipose tissue of mice kept on SFD or HFD, as measured by Sirius red staining. Stained area $(\%$ of section area measured) 
Fig. 3 Glucose tolerance test in mice kept on SFD (ם) or HFD (O) for 15 weeks. Blood glucose levels were measured at different times after intraperitoneal injection of glucose $(2 \mathrm{mg} / \mathrm{g}$ body weight). Data are mean \pm SEM of 6 experiments. $*$ and ${ }^{* *}, \mathrm{p}<0.05$ and $\mathrm{p}<0.005$ versus SFD

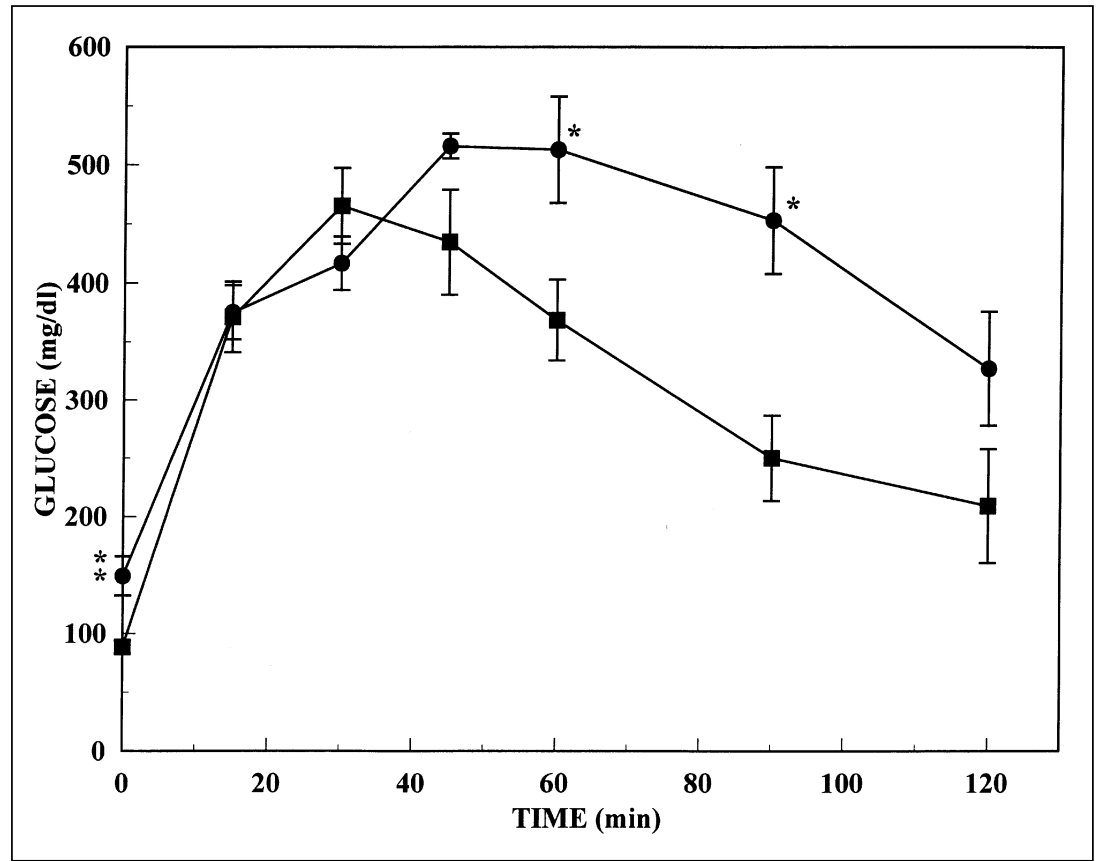

The weight of other organs, including lung, kidney, spleen and heart was very similar for SFD or HFD feeding of wild-type mice for 15 weeks, whereas the liver was $10-20 \%$ heavier on HFD feeding (not shown).
The food intake of wild-type mice on SFD or HFD was not significantly different: $3.7 \pm 0.09 \mathrm{~g} / 24 \mathrm{~h}$ versus $3.5 \pm 0.18 \mathrm{~g} / 24 \mathrm{~h}$ (mean \pm SEM of 16-18 measurements). Physical activity at night was also comparable for mice on SFD or HFD: 8,200 $\pm 2,200$ cycles/12 h
Table 3 Metabolic and haematologic parameters of mice kept on SFD or HFD

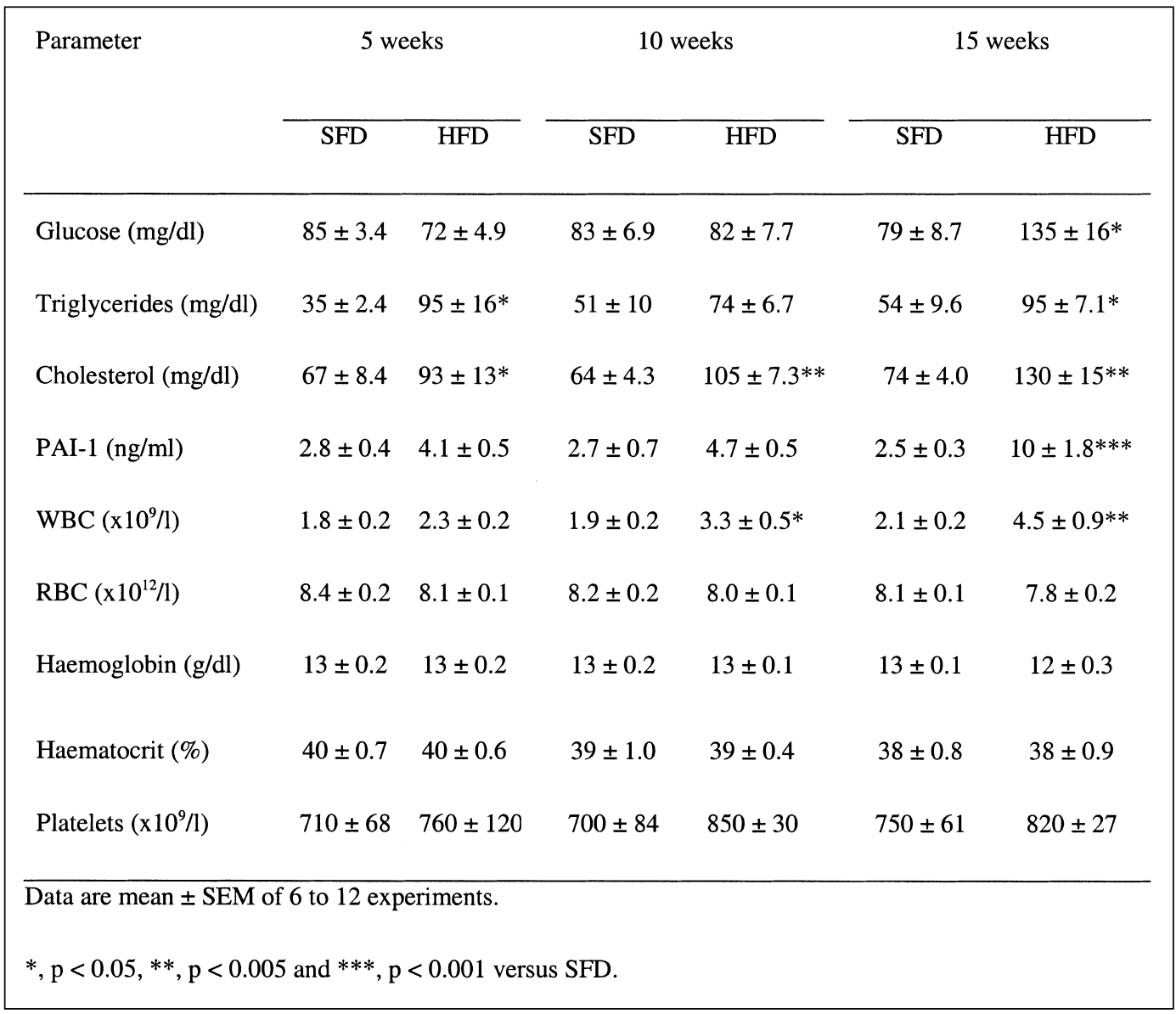




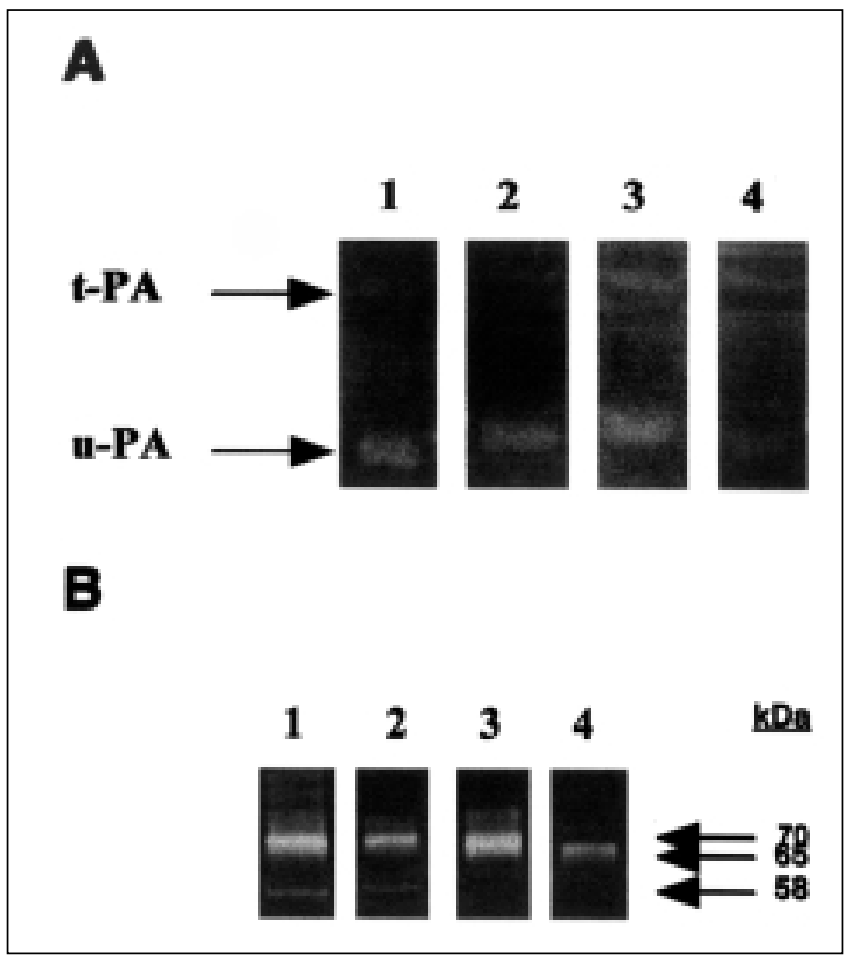

Fig. 4 Zymographic analysis of adipose tissue extracts. Extracts of SC (lanes 1 and 2) or GON (lanes 3 and 4) adipose tissue obtained from mice kept on SFD (lanes 1 and 3) or HFD (lanes 2 and 4) for 15 weeks were applied to casein (panel A) or gelatin (panel B) containing gels

versus $8,600 \pm 620$ cycles/ $12 \mathrm{~h}$ (mean \pm SEM of 7-8 measurements); during the day physical activity was very low and was also comparable for both regimens.

\section{Cellularity of Adipose Tissue}

In both SC and GON fat pads, the mean diameter of the adipocytes increased with time, and was significantly higher in the mice on HFD as compared to SFD (Table 1 and Fig. 2, A and C). Thus, after 15 weeks of HFD the mean volume of adipocytes in the SC or GON tissues was increased by a factor of 5.2 or 4.1 respectively, as compared to the SFD. The volume of adipocytes in the GON tissue was larger than in the SC tissue: 2.0 fold or 1.6-fold after 15 weeks of SFD or HFD respectively. Staining of adipose tissue sections with Sirius red (Fig. 2, B and D) showed the presence of fibrillar collagen throughout the sections. Quantitation of the stained area revealed that the collagen content in SC or GON adipose tissue of mice on HFD was lower than on SFD (Table 2).

\section{Haematologic and Metabolic Parameters}

Plasma haematologic parameters, including red blood cells, platelets, haemoglobin and haematocrit levels in mice fed the SFD or HFD did not change significantly with age, and were not different between both diets. White blood cell counts were higher after 10 and 15 weeks of HFD, as compared to the SFD. Plasma PAI-1 levels after 15 weeks of HFD were significantly enhanced (Table 3).

The HFD induced marked hyperglycemia, with glucose levels increasing with duration of diet; after 15 weeks of HFD the level was significantly enhanced as compared to the SFD $(\mathrm{p}<0.05)$ (Table 3$)$. Glucose tolerance tests after 15 weeks of SFD or HFD feeding revealed higher blood glucose levels at 45 to $120 \mathrm{~min}$ after intraperitoneal glucose injection in the mice on HFD (Fig. 3). At each time point, plasma triglycerides and total cholesterol were higher on the HFD (Table 3).

\section{Fibrinolytic and MMP System Components in Adipose Tissue}

In extracts of SC or GON adipose tissue, PAI-1, t-PA and u-PA antigen levels at 5, 10 or 15 weeks were overall comparable or somewhat lower for the HFD groups (Table 4). Zymography on caseincontaining gels confirmed the presence of t-PA and u-PA activity (Fig. 4A). At the different time points, t-PA and u-PA activities were lower in the $\mathrm{SC}$ and in the GON adipose tissue of the mice on HFD.

Zymography of extracts on gelatin-containing gels revealed the presence of $70 \mathrm{kDa}$ and $65 \mathrm{kDa}$ proMMP-2 forms and of $58 \mathrm{kDa}$ active MMP-2 (Table 4 and Fig. 4B). The most striking observation was the virtual absence of active MMP-2 in GON adipose tissue of mice on SFD, whereas it was present in that of mice on HFD. In contrast, active MMP-2 levels in the SC tissue were somewhat lower in the HFD groups. (Pro)MMP-9 was not consistently detected. However, MMP-9

Table 4 Fibrinolytic and MMP system components in adipose tissue of mice kept on SFD or HFD

\begin{tabular}{|c|c|c|c|c|c|c|c|c|c|c|c|c|}
\hline & \multicolumn{4}{|c|}{5 weeks } & \multicolumn{4}{|c|}{10 weeks } & \multicolumn{4}{|c|}{15 weeks } \\
\hline & \multicolumn{2}{|c|}{$\mathrm{SC}$} & \multicolumn{2}{|c|}{ GON } & \multicolumn{2}{|c|}{ SC } & \multicolumn{2}{|c|}{ GON } & \multicolumn{2}{|c|}{ SC } & \multicolumn{2}{|c|}{ GON } \\
\hline & SFD & HFD & SFD & HFD & SFD & HFD & SFD & HFD & SFD & HFD & SFD & HFD \\
\hline Protein $(\mathrm{mg} / \mathrm{g})^{\mathrm{a}}$ & $30 \pm 3.4$ & $15 \pm 3.4^{*}$ & $18 \pm 1.8$ & $8.1 \pm 0.9^{* * *}$ & $25 \pm 3.5$ & $13 \pm 1.5^{*}$ & $21 \pm 4.0$ & $7.2 \pm 0.6^{* *}$ & $22 \pm 8.0$ & $13 \pm 1.3$ & $27 \pm 3.0$ & $13 \pm 3.0^{*}$ \\
\hline PAI-1 antigen ${ }^{\mathrm{b}}(\mathrm{ng} / \mathrm{g})$ & $41 \pm 8.4$ & $15 \pm 2.3 * *$ & $18 \pm 1.0$ & $13 \pm 2.1^{*}$ & $25 \pm 4.5$ & $15 \pm 2.0$ & $23 \pm 5.1$ & $13 \pm 1.3 *$ & $20 \pm 5.7$ & $19 \pm 2.4$ & $15 \pm 2.5$ & $18 \pm 1.8$ \\
\hline t-PA antigen ${ }^{b}(n g / g)$ & $20 \pm 3.3$ & $12 \pm 2.6$ & $13 \pm 1.3$ & $9.1 \pm 1.1^{*}$ & $20 \pm 5.2$ & $14 \pm 1.5$ & $17 \pm 4.9$ & $9.1 \pm 0.9$ & $8.5 \pm 0.5$ & $11 \pm 0.8$ & $10 \pm 1.3$ & $11 \pm 1.3$ \\
\hline t-PA activity $(\mathrm{AU} / \mathrm{g})$ & $310 \pm 130$ & $28 \pm 18^{*}$ & $220 \pm 65$ & $79 \pm 24$ & $350 \pm 100$ & $32 \pm 14$ & $200 \pm 120$ & $140 \pm 17$ & $130 \pm 90$ & $17 \pm 7.8$ & $230 \pm 60$ & $32 \pm 20^{*}$ \\
\hline u-PA antigen $(n g / g)$ & $54 \pm 5.8$ & $48 \pm 8.4$ & $50 \pm 11$ & $31 \pm 3.7$ & $45 \pm 10$ & $38 \pm 3.5$ & $62 \pm 24$ & $33 \pm 5.5$ & $76 \pm 16$ & $50 \pm 9.4$ & $72 \pm 12$ & $56 \pm 6.6$ \\
\hline u-PA activity $(\mathrm{AU} / \mathrm{g}$ ) & $1300 \pm 320$ & $360 \pm 75^{*}$ & $1100 \pm 170$ & $300 \pm 33^{*}$ & $1700 \pm 280$ & $460 \pm 58 * *$ & $1000 \pm 440$ & $320 \pm 60$ & $2300+620$ & $500 \pm 140$ & $1000 \pm 120$ & $190 \pm 72 *$ \\
\hline $70 \mathrm{kDa}$ proMMP-2 $(\mathrm{AU} / \mathrm{g})$ & $740 \pm 260$ & $610 \pm 220$ & $850 \pm 260$ & $440 \pm 160$ & $2300 \pm 1800$ & $420 \pm 150$ & $810 \pm 450$ & $160 \pm 30$ & $1600 \pm 1000$ & $320 \pm 220$ & $1300 \pm 440$ & $75 \pm 35^{*}$ \\
\hline $65 \mathrm{kDa}$ proMMP-2 $(\mathrm{AU} / \mathrm{g})$ & $4100 \pm 950$ & $3100 \pm 1200$ & $3100 \pm 620$ & $1700 \pm 510$ & $4400 \pm 3100$ & $2300 \pm 360$ & $3600 \pm 1800$ & $1000 \pm 240$ & $5600 \pm 2100$ & $1500 \pm 780$ & $6100 \pm 1900$ & $940 \pm 340^{*}$ \\
\hline $58 \mathrm{kDa}$ MMP-2 $2^{\mathrm{c}}(\mathrm{AU} / \mathrm{g})$ & $1100 \pm 990$ & $500 \pm 290$ & N.D. & $60 \pm 47$ & $370 \pm 320$ & $220 \pm 95$ & N.D. & $67 \pm 23$ & $840 \pm 480$ & $240 \pm 140$ & N.D. & $54 \pm 34$ \\
\hline
\end{tabular}


Fig. 5 MMP-9 mRNA determination in $\mathrm{SC}$ and GON adipose tissue derived from wild-type mice kept on SFD or HFD, and in isolated adipocytes (Adip.) or stromal-vascular (S-V) cells derived from these tissues. The ratio between MMP-9 mRNA and 28S rRNA is indicated at the bottom of the panels. Lane (-) indicates a blank control without sample

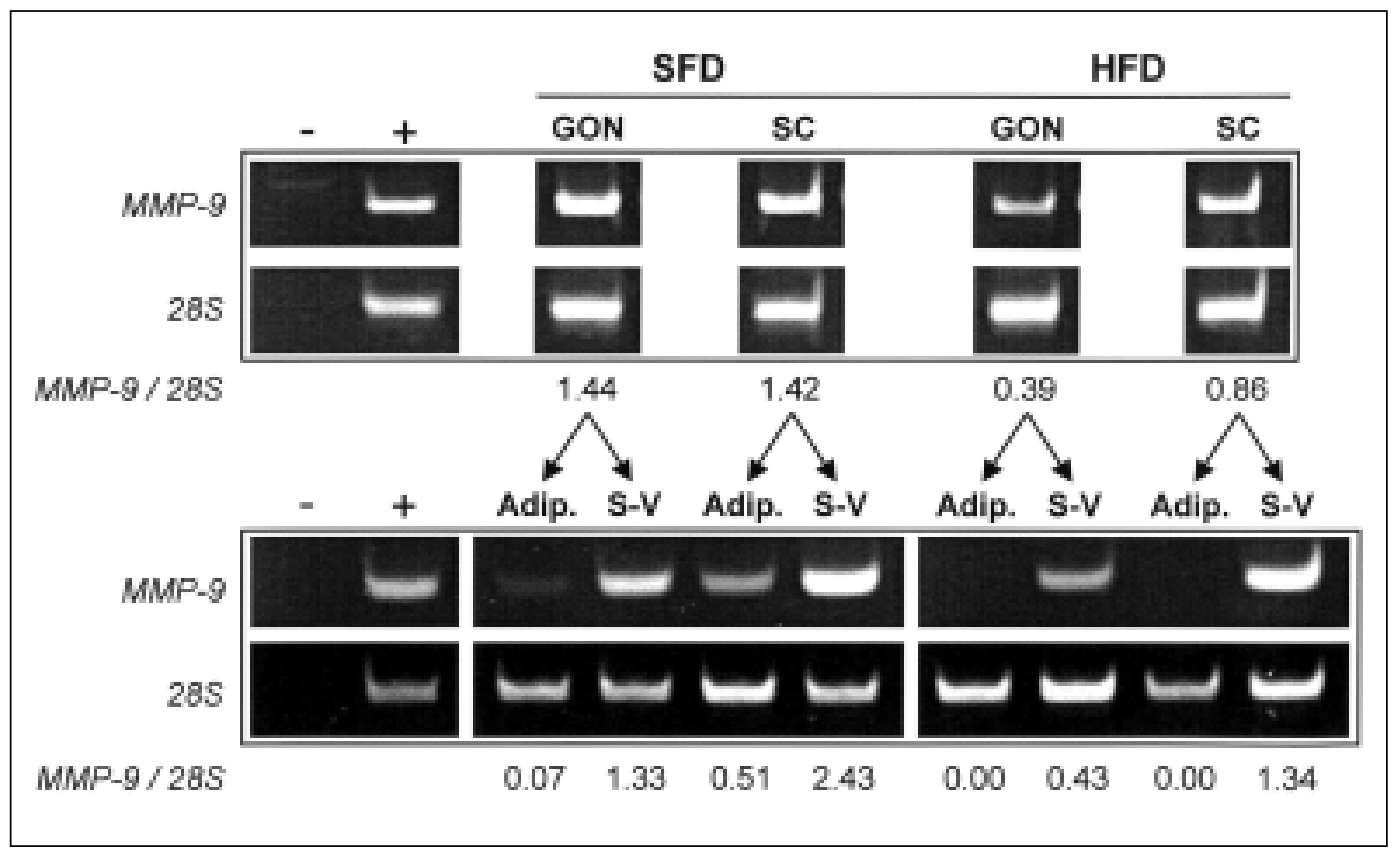

mRNA levels in both SC and GON adipose tissue and in isolated adipocytes and stromal-vascular cells, determined by semi-quantitative RT-PCR, appeared to be downregulated on the HFD, and it was expressed mainly in the stromal-vascular cell fraction (Fig. 5).

In situ zymography with fibrin-containing gels on cryosections of SC or GON adipose tissue did not reveal different fibrinolytic activity after 15 weeks of SFD or HFD (Table 5). Addition of anti-t-PA antibodies virtually abolished the fibrinolytic activity, indicating that it is mainly t-PA dependent (not shown).

In situ zymography with casein- or gelatin-containing gels on cryosections of SC or GON adipose tissue confirmed the presence of MMP activity in the tissue. After 15 weeks of HFD, the caseinolytic activity in SC and GON adipose tissue was significantly higher, but the gelatinolytic activity significantly lower, as compared to the SFD (Table 5). Addition of a mixture of EDTA (final concentration $25 \mathrm{mmol} / \mathrm{L}$ ) and 1,10 phenanthroline (final concentration $5 \mathrm{mmol} / \mathrm{L}$ ) to the agarose gel resulted in inhibition of the lytic activity to $40 \pm 7.4 \%$ $(n=24)$ of control in the casein overlays and to $33 \pm 7.3 \%(n=22)$ of control in the gelatin overlays (not shown).

\section{Disc ussion}

The molecular mechanisms involved in development of obesity remain largely unknown, partly due to the lack of appropriate quantitative models. Development of obesity is associated with an extensive reorganization of the adipose tissue involving adipogenesis, angiogenesis and ECM remodeling. The ECM does not only function as a structural support, but also affects cell-cell interactions and processes such as differentiation and migration that may be required for the cellular reorganization of fat pads and for regulation of the expression of adipocyte genes (21-24). Because of the multiple functions attributed to the plasminogen/plasmin and MMP systems it is likely that these affect several cellular processes in adipose tissue. Proteinases of both systems are, indeed, collectively able to cleave a wide variety of substrates,
Table 5 Fibrinolytic, gelatinolytic and caseinolytic activity in adipose tissue of mice kept on SFD or HFD for 15 weeks, as measured by in situ zymography
Lysis/section area

\begin{tabular}{lcccc}
\cline { 3 - 4 } & & Fibrin & Gelatin & Casein \\
\hline SC & SFD & $0.47 \pm 0.070$ & $0.22 \pm 0.046$ & $0.11 \pm 0.016$ \\
& HFD & $0.52 \pm 0.072$ & $0.08 \pm 0.027^{*}$ & $0.19 \pm 0.034^{*}$ \\
& & & & \\
GON & SFD & $0.40 \pm 0.057$ & $0.30 \pm 0.031$ & $0.088 \pm 0.016$ \\
& & & & \\
& HFD & $0.36 \pm 0.047$ & $0.033 \pm 0.007^{* *}$ & $0.22 \pm 0.041^{* *}$
\end{tabular}

Data are mean \pm SEM of 5 to 7 determinations.

${ }^{*}, \mathrm{p} \leq 0.05$ and ${ }^{* *}, \mathrm{p} \leq 0.005$ versus SFD. 
including ECM components, other proteinases and their inhibitors, and matrix receptors (25), whereby adipose tissue remodeling may be facilitated. Furthermore, adipocytes are surrounded by a basement membrane (26) that has to be extensively remodeled in order to allow the hypertrophic development of adipocytes observed in obesity. MMPs and plasmin can also release, activate or degrade several growth factors and cytokines (25) implicated in obesity and play major roles in angiogenesis (27), an essential process in adipose tissue development (1).

We have used a nutritionally induced obesity model in mice to study a potential role of fibrinolytic or gelatinolytic activity in development of adipose tissue.

The model involves the administration to 5 week old mice of a high fat diet (HFD) for periods up to 15 weeks. Preferentially male mice are used in order to avoid large differences in body weight that may be due to hormonal effects on synthesis or secretion of components of the system under evaluation, or of other systems that may play a role in development of adipose tissue. A head to head comparison of obesity in male and female wild-type mice kept on the HFD has however not been made. The model is characterized by a significantly faster gain of body weight in the mice on HFD (from the third week on) as compared to standard chow; this can be partly explained by adipocyte hypertrophy. The observed difference in SC and GON adipose tissue weight of mice kept on HFD does apparently not explain the large difference in total body weight. It should be kept in mind, however, that not all the body fat is recovered. Furthermore, the finding that food intake and physical activity is comparable for mice on SFD and HFD and that the weight of other organs is not significantly different, suggests that the observed obesity is mainly due to increased fat pad weights. Analysis of metabolic parameters revealed higher triglyceride and cholesterol levels for the mice on HFD at different time periods. Glucose levels were significantly enhanced after 15 weeks of HFD, and during glucose tolerance tests.

The collagen content in the adipose tissue was lower in the mice on HFD. This appears in agreement with the higher MMP-related in situ caseinolytic activity observed in SC and GON adipose tissue from mice on HFD. In contrast, in situ gelatinolytic activity was lower in the HFD groups, as was the (pro) MMP-2 content in the adipose tissue extracts. The apparent discrepancy between the absence of active $58 \mathrm{kDa}$ MMP-2 in GON adipose tissue extracts of mice on SFD (Table 4) and the higher level of gelatinolytic activity measured by in situ zymography (Table 5) may be due to the fact that the latter method detects all proteinases with gelatinolytic activity. Because (pro)MMP-9 was not consistently detected in extracts of the adipose tissue, we have monitored its mRNA levels. Semi-quantitative RT-PCR revealed expression of MMP-9 in both SC and GON adipose tissue, which was downregulated on the HFD; expression was observed mainly in the stromal-vascular cell fraction. MMP-2 mRNA was also previously reported in adipocytes and in the stromal-vascular cells (12). In extracts of adipose tissue, t-PA, u-PA and PAI-1 levels were in general lower in the HFD groups, but in situ fibrin overlays did not show a significant difference. This may be due to the fact that fibrin overlay essentially detects t-PA activity, representing a balance between t-PA and PAI-1 activity. During the time course, plasma PAI-1 levels were always higher in mice on the HFD. Recently, it was shown that PAI-1 production in human adipose tissue is associated mainly with stromal cells, which are more abundant in visceral than in subcutaneous fat (28). This may explain the strong correlation between circulating PAI-1 levels and the accumulation of visceral fat in humans.

We have focused on monitoring main components of the fibrinolytic system, because previous studies in mice with deficiency of t-PA, u-PA or PAI-1 kept on HFD have revealed a potential role $(9,29)$. These studies suggested that the t-PA/PAI-1 pathway but not the u-PA/PAI-1 pathway plays a role in adipose tissue development, as t-PA deficient mice showed more marked obesity when kept on HFD than their wild-type counterparts (29). In agreement with this finding, we have observed throughout the time course significantly lower t-PA activity levels in extracts of SC and GON adipose tissue from the obese mice on HFD. We have also focused on the gelatinases because their expression has been observed in adipose tissue of nutritionally induced and genetically obese mice (12), as well as in that of humans (13). Recently, it was observed that galardin, a hydroxamate-based broad spectrum MMP inhibitor reduces adipose tissue weight in this model (30).

The data obtained in this time course study of development of adipose tissue thus are compatible with a potential role of fibrinolytic and/or gelatinolytic activity. The molecular mechanisms of these interactions remain to be further detailed. Plasmin-mediated proteolytic activity may directly degrade some matrix components, or indirectly via activation of matrix metalloproteinases.

\section{Acknowledgements}

Skilful technical assistance by F. De Cock, A. De Wolf, L. Frederix and M. Verstreken is gratefully acknowledged. This study was supported by a grant from the Interuniversity Attraction Poles (IUAP, P5/O2) and from the Flemish Fund for Scientific Research (FWO-Vlaanderen, G.0138.00).

\section{References}

1. Crandall DL, Hausman GJ, Kral JG. A review of the microcirculation of adipose tissue: anatomic, metabolic, and angiogenic perspectives. Microcirculation 1997; 4: 211-32.

2. Dollery CM, McEwan JR, Henney AM. Matrix metalloproteinases and cardiovascular disease. Circ Res 1995; 77: 863-8.

3. Carmeliet P, Collen D. Development and disease in proteinase-deficient mice: role of the plasminogen, matrix metalloproteinase and coagulation system. Thromb Res 1998; 91: 255-85.

4. Lijnen HR. Plasmin and matrix metalloproteinases in vascular remodeling. Thromb Haemost 2001; 86: 324-33.

5. Samad F, Yamamoto K, Loskutoff DJ. Distribution and regulation of plasminogen activator inhibitor-1 in murine adipose tissue in vivo: induction by tumor necrosis factor- $\alpha$ and lipopolysaccharide. J Clin Invest 1996; 97: 37-46.

6. Alessi MC, Peiretti F, Morange P, Henry M, Nalbone G, Juhan-Vague I. Production of plasminogen activator inhibitor 1 by human adipose tissue. Possible link between visceral fat accumulation and vascular disease. Diabetes 1997; 46: 860-7.

7. Juhan-Vague I, Alessi MC. Regulation of fibrinolysis in the development of atherothrombosis: role of adipose tissue. Thromb Haemost 1999; 82: 832-6.

8. Samad F, Loskutoff DJ. Hemostatic gene expression and vascular disease in obesity: insights from studies of genetically obese mice. Thromb Haemost 1999; 82: 742-7.

9. Morange PE, Lijnen HR, Alessi MC, Kopp F, Collen D, Juhan-Vague I. Influence of PAI-1 on adipose tissue growth and on metabolic parameters in a murine model of diet-induced obesity. Arterioscler Thromb Vasc Biol 2000; 20: 1150-4.

10. Ėren M, Su M, Atkinson J, King L, Declerck P, Vaughan DE. Phenotypic derangements associated with overexpression of plasminogen activator inhibitor-1 (PAI-1) in transgenic mice. Arterioscler Thromb Vasc Biol 2001; 21: 695 (Abstract 230).

11. Brown LM, Fox HL, Hazen SA, LaNoue KF, Rannels SR, Lynch CJ. Role of the matrixin MMP-2 in multicellular organization of adipocytes cultured in basement membrane components. Am J Physiol 1997; 272: C937-C949. 
12. Lijnen HR, Maquoi E, Holvoet P, Mertens A, Lupu F, Morange P, Alessi $\mathrm{MC}$, Juhan-Vague I. Adipose tissue expression of gelatinases in mouse models of obesity. Thromb Haemost 2001; 85: 1111-6.

13. Bouloumié A, Sengenès C, Portolan G, Galitzky J, Lafontan M. Adipocyte produces matrix metalloproteinases 2 and 9. Involvement in adipocyte differentiation. Diabetes 2001; 50: 2080-6.

14. Maquoi E, Munaut C, Colige A, Collen D, Lijnen HR. Modulation of adipose tissue expression of murine matrix metalloproteinases and their tissue inhibitors with obesity. Diabetes 2002; 51(4): 1093-101.

15. Giles AR. Guidelines for the use of animals in biomedical research. Thromb Haemost 1987; 58: 1078-84.

16. Declerck PJ, Verstreken M, Collen D. Immunoassay of murine t-PA, u-PA and PAI-1 using monoclonal antibodies raised in gene-inactivated mice. Thromb Haemost 1995; 74: 1305-9.

17. Lijnen HR, Van Hoef B, Lupu F, Moons L, Carmeliet P, Collen D. Function of plasminogen/plasmin and matrix metalloproteinase systems after vascular injury in mice with targeted inactivation of fibrinolytic system genes. Arterioscler Thromb Vasc Biol 1998; 18: 1035-45.

18. Kleiner DE, Stetler Stevenson WG. Quantitative zymography: detection of picogram quantities of gelatinases. Anal Biochem 1994; 218: 325-9.

19. Galis ZS, Sukhova GK, Libby P. Microscopic localization of active proteases by in situ zymography: detection of matrix metalloproteinase activity in vascular tissue. FASEB J 1995; 9: 974-80.

20. Rodbell M. Metabolism of isolated fat cells. I. Effects of hormones on glucose metabolism and lipolysis. J Biol Chem 1964; 239: 375-80.

21. Kubo Y, Kaidzu S, Nakajima I, Takenouchi K, Nakamura F. Organization of extracellular matrix components during differentiation of adipocytes in long-term culture. In Vitro Cell Dev Biol Anim 2000; 36: 38-44.

22. Nakajima I, Yamaguchi T, Ozutsumi K, Aso H. Adipose tissue extracellular matrix: newly organized by adipocytes during differentiation. Differentiation 1998; 63: 193-200.
23. Kuri-Harcuch W, Arguello C, Marsch-Moreno M. Extracellular matrix production by mouse 3T3-F442A cells during adipose differentiation in culture. Differentiation 1984; 28: 173-8.

24. Zangani D, Darcy KM, Masso-Welch PA, Bellamy ES, Desole MS, Ip MM. Multiple differentiation pathways of rat mammary stromal cells in vitro: acquisition of a fibroblast, adipocyte or endothelial phenotype is dependent on hormonal and extracellular matrix stimulation. Differentiation 1999; 64: 91-101.

25. McCawley LJ, Matrisian LM. Matrix metalloproteinases: multi-functional contributors to tumor progression. Mol Med Today 2000; 6: 149-56.

26. Pierleoni C, Verdenelli F, Castellucci M, Cinti S. Fibronectins and basal lamina molecules expression in human subcutaneous white adipose tissue. Eur J Histochem 1998; 42: 183-8.

27. Stetler-Stevenson WG. Matrix metalloproteinases in angiogenesis: a moving target for therapeutic intervention. J Clin Invest 1999; 103: 1237-41.

28. Bastelica D, Morange P, Berthet B, Borghi H, Lacroix O, Grino M, Juhan-Vague I, Alessi M-C. Stromal cells are the main plasminogen activator inhibitor-1 producing cells in human fat. Evidence of differences between visceral and subcutaneous deposits. Arterioscl Thromb Vasc Biol 2002; 22: 173-8.

29. Morange PE, Bastelica D, Bonzi MF, Van Hoef B, Collen D, Juhan-Vague I, Lijnen HR. Influence of t-PA and u-PA on adipose tissue development in a murine model of diet-induced obesity. Thromb Haemost 2002; 87 (2); 306-10.

30. Lijnen HR, Maquoi E, Hansen LB, Van Hoef B, Frederix L, Collen D. Matrix metalloproteinase inhibition impairs adipose tissue development in mice. Arterioscler Thromb Vasc Biol 2002; 22(3): 374-9.

Received February 18, 2002 Accepted after revision April 22, 2002 